\title{
Dr. B.R. Ambedkar Thoughts on Atmanirbhar Bharat in Special Reference Indo-China Dispute
}

\author{
Sunil. S. Warbhuvan \\ (BE, MMCJ, LL.M, Ph.D. in Law, Ph.D. in Journalism) \\ House Number: 5-7-58, Bhimpura, Osmanpura, Aurangabad, Maharashtra, India \\ E-mail: sunilwarbhuvan@gmail.com
}

Received: May 9, 2021 Accepted: June 20, $2021 \quad$ Published: July 2, 2021

doi:10.5296/ijssr.v9i2.18827 URL: https://doi.org/10.5296/ijssr.v9i2.18827

\begin{abstract}
The present issue of Indo-China dispute is focusing different aspects like trade, military stand-offs global ambition, international policy, etc. so where do the faultslie in this relation between the two Asian giants, struggling on either side of Himalaya. India and China both are high populated and world's ancient civilization neighboring countries connected by Buddhism. Presently huge gathering of military forces deployment is being seen at the borders of Leh on the part of China. India become cautious for protecting its sovereignty. Both started rounds of diplomatic dialogue to turn the situation in to peace by discussion. In this research paper it is studied that how Indo-China dispute can be sorted out by adopting middle path solution for welfare of both countries for peace instead of war. On this platform prime minister Narendra Modi started campaign 'Atmanirbhar Bharat' his objective of starting Atmanirbhar Bharat campaign aimed to be that our Nation should be self-reliant with strong socio-economy to make more competent for war. Now here objective and aim are clear but remedy he has not clearly announced. So to achieve objective of making India strong nation through socio-economic development is the basic problem in this study India should think permanent solution. Buddha said 'Atta Dip Bhava' which means be a light means self-reliant likewise. In this study Dr. B.R. Ambedkar who was chairman of drafting committee of Indian constitution, his thoughts for permanent solution are directive, beneficial and agreeable in Indian context.
\end{abstract}

Keywords: Dr. B.R. Ambedkar, Indo-China relations, Atmanirbhar Bharat, dispute resolution, socio-economic impact 


\section{Introduction}

$21^{\text {st }}$ century came with new challenges and opportunities for India. Our neighboring country China is presently emerging super power. Our new challenge is that the "Naval analysts say as Beijing makes creeping territorial claims in Himalayas the world's largest Navy aggressively expanding its presence in the Indian Ocean region" (Sandeep, 2020). Presently China communist party is governing the actions. Communist party believes on communism which advocated the common sharing of all resources by all as needed. Single party ruling is unquestioned leadership to the people of the China.

India needs to be Atmanirbhar Bharat to solve Indo-China dispute on the direction of social, economic, political thought of Bharat Ratna Dr. B.R. Ambedkar. At present politically all citizens are equal but socially and economically they are not equal. It does not give successful democracy socioeconomic tool Indian constitution should execute appropriately by legislative, executive, judiciary, media to make welfare state. Strong democracy with welfare state will be necessary for making Atmanirbhar Bharat in real sense. Free education for all and free medical facility for all by government as per socio-economic thought of Dr. B.R. Ambedkar will help young generation and all citizens as a proper human resource to make India a strong nation. Right to employment/work should seriously executed in India. In covid-19 poor population could not take education, medical facility moreover they lost their employment. Participation of government institution matters in development process and emergency duty but due to rapid privatization policy execution in India made paralyzed the basic services like education, health facilities even though government is taking income tax mandatorily. Strong democratic welfare state will have successful dialogue with any nation. Neither Indian nor Chinese are interested in war. Moreover, nobody in the world is interested in the war all want peace. This friction is due to collective personnel interest of some capitalist with some politicians of the country. It is the legal, moral, social responsibility of each citizen of India to act in the Indian constitutional frame which is legal thought of Dr. B.R. Ambedkar to make India strong and Atmanirbhar Bharat. It automatically helps in cooperating QUAD members and China instead of dispute.

\section{Background}

History of communism governance started from USSR who executed expansion program. China also started controlling Tibet and attacked northeast region of India showed examples of expansion program. It is rightly quoted the warning focused in Rajya Sabha debate by Dr. B.R. Ambedkar that "Mr. Nehru's policy should be examined against allowing the Chinese communists to take Lhasa, had helped China to bring her borders right down to the fringe of India” (Rajya, 1954). Dr. B.R. Ambedkar suggested that the merits of SEATO (southeast Asia treaty organization) must be considered so that China should not be allowed occupy any further part of the free world" SEATO was formed 08 September 1954. In it total 08 members were their namely Australia, France, New Zealand, Pakistan, Philippines, Thailand, United Kingdom, United states. It was intergovernmental alliance for anti-communist bilateral collective defense treaty. Nehru government did not consider. Dr. B.R. Ambedkar's advice and all knows that 1962 Indo-China war happened and India defeated. 
In present 2019-2020 issue of Indo-China border India must be strong enough before the emerging economic super power. Strong India means united India but if the statistical data is surveyed it shows that upper caste less populated class have more representation and more populated lower class is having less representation in governance which indicates Indian population is divided in upper and lower caste

\section{Literature Review}

In present article it is tried to refer to above history of policymaking in present 2019-2020. It is very interestingly noted by Bidanda Chengappa, regarding Indo-China foreign policy that, 'India's China policy over the past seven decades is largely shaped by its political vision, economic diplomacy and military capability; considering the two neighbors share a disputed border with each other. New Delhi's political vision and diplomacy towards Beijing is based on military. Indian foreign policy makers formulate policy towards China referring 1962 Indo-China war, Indian defeat was one that happened because of lack of military capability (Bidanda, 2020). According to The Stockholm's International Peace Research Institute (SIPRI) in 2019, China's defense budget was \$261 Billion, while the corresponding figure for India was $\$ 71.1$ Billion. Hence increase in the funding for military is important for increasing the military capability of India. Now the scenario is changed again from 1962 to 2021 in almost 58 years. It is again required to refer Dr. B.R. Ambedkar's direction in the present time. In this article it is studied.

India large democratic power is concentrating for good relation towards America, another old democratic super power in the world. It is pointed by Shyam Saran, a former foreign secretary that "The violent assault on the American capitol building by pro-trump mob, this is bad news for those who still rely on US to enable a credible coalition to restrain China. He added that with America's geopolitical clout in doubt, India will now face a less restrained China, one which wants to remake the world to suit its own interests. What this means for India is facing up bumpy ride ahead" (Shyam, 2020). On this platform Atmanirbhar Bharat, which translates to 'self-reliant India' or 'self-sufficient India', is the vision of the Prime Minister of India Narendra Modi of making India "a bigger and more important part of global economy", perusing policies that are efficient, competitive and resilient, and being self-sustaining and self-generating. Atmanirbhar Bharat does not mean "self-containment", "isolating away from world" or being "protectionist". The first mention of this came in the form of the 'Atmanirbhar Bharat Abhiyan' or 'self-reliant India mission during the announcement of India's COVID-19 pandemic related economic package on $12^{\text {th }}$ May 2020. The five pillars of 'Atmanirbhar Bharat' are stated as economy, infrastructure, technology driven system, vibrant demography and demand. But the ground realities are different to make India Atmanirbhar Bharat. Delhi decided Atmanirbhar campaign but remedial actions are not clear that how Atmanirbhar Bharat will be made?

It is very interestingly noted by AlamSrinivas that, "there is beauty, and huge blemish to Prime Minister Narendra Modi's Atmanirbhar Bharat crusade. It appeals to different individuals in diverse ways. Some see it as a $21^{\text {st }}$ Century vision of Gandhi's call to embrace of swadeshi, an intoxicating cocktail of nationalism, capitalism and globalization. Others look 
at it as a magical melting pot of patriotism, self-confidence, and national ambitions. In the process, it turns out to be chaotic and confusing blend of beliefs based on fuzzy logic" (Alam, 2020). In this article it is studied that in view of Dr. B.R. Ambedkar in constitutional debate how India can become Atmanirbhar Bharat. Freedom fighter had their dreams about India. It is said that, "Indian Constitution is the socio-economic tool to make socio-economic progress" (Basu, n.d.).

The preamble of the constitution states as follows,

'WE THE PROPLE OF INDIA, having solemnly resolved to constitute India into a [SOVEREIGN SOCIALIST SECULAR DEMOCRATIC REPUBLIC] and to secure to all its citizens: JUSTICE, social, economic and political; LIBERTY of thought, expression, belief, faith and worship; EQUALITY of status and of opportunity; and to promote among them all. FRATERNITY assuring the dignity of the individual and the [unity and integrity of the Nation].'

It is noted that the Credit Censes of Global Wealth Data-book for 2014 reports bottom 10\% of Indian society owned merely $0.2 \%$ National Wealth, while richest $10 \%$ have been getting steadily richer since 2000 .

Table 1.

\begin{tabular}{ll}
\hline Social Class \% & Wealth Share $\%$ \\
\hline Bottom 10 & 0.2 \\
$10-20$ & 0.4 \\
$20-30$ & 0.8 \\
$30-40$ & 0.3 \\
$40-50$ & 0.8 \\
$50-60$ & 2.6 \\
$60-70$ & 3.8 \\
$70-80$ & 5.7 \\
$80-90$ & 9.4 \\
Top 10 & 77 \\
\hline
\end{tabular}

N.C. Saxena, a member of the National Advisory Council suggested that the widening income disparity can be accounted for by India's badly shaped agricultural and rural safety nets. Dreams of freedom fighters and real social survey data are controversial. It means constitutional provisions are not executed properly. In 58 years period govt. did not able to make economic equality. Art51: says that 'the state shall endeavor to: a: Promote international peace and security; regarding this provision it is pointed by Dr. Pradeep Aglave on talk on Nazism that "Dr. B.R. Ambedkar at time of $2^{\text {nd }}$ world war (3 September 1939 to 10 august 1945) on 12 September 1939 announced support to Britain through independent labor party to support democratic thought of Britain and to oppose dictatorship of Germany" 
(speech of Dr. Aglave). Maintain just and honorable relations between nations; regarding this provision Dr. Pradeep Aglave added that even congress having discussion that war is making violence. Violence should not be supported as per the opinion of Mahatma Gandhi. Dr. B.R. Ambedkar explained that in war there will be violence but still why I gave support to Britain because after war, who should be winner is a deciding factor. $2^{\text {nd }}$ world war is the war between two thoughts one is democratic political system of governance another is dictatorship political system of governance. In this independent labor party in India want to win democratic political system of governance. This indicates that Dr. Ambedkar as a foreign policy maker directed that international brotherhood and freedom principles are very important. Foster respect for international law and treaty obligations in dealings of organized peoples with one another; "regarding this provision in the research paper named small Holdings in India and their remedies in the 'journal of Indian economic society' in 1918 Dr. Ambedkar suggested nationalization of agricultural land” (Somvanshi, 2012).

To become more organized because of rich poor gap in India. Social and economic equality will make India strong. Strong India will foster respect in international community to execute international law properly. Encourage settlement of international disputes by arbitration. Regarding this provision and for recent Indo-China dispute it is require to encourage settlement of international dispute by arbitration but for that it is said by Darwin that "the fittest will survive in this world" this means India should be fit in social, economic, political, cultural aspects with China at present India has trade deficit with China that is Indian import is more from China and Indian export is less in China. The scenario will change if India adopts economic policy like China. India should boost basic and mass companies' public sector undertakings instead of disinvestment so that unemployment problem will be solved. It is very interestingly noted by Bidanda Chengappa, regarding Indo-China foreign policy that, 'India's China policy over the past seven decades is largely shaped by its political vision, economic diplomacy and military capability; considering the two neighbors share a disputed border with each other. New Delhi's political vision and diplomacy towards Beijing is one based on military. Indian foreign policy makers formulate policy towards China referring 1962 Indo-China war, Indian defeat was one that happened because of lack of military capability (Supra 2). According to The Stockholm's International Peace Research Institute (SIPRI) in 2019, China's defense budget was \$261 Billion, while the corresponding figure for India was $\$ 71.1$ Billion. Hence increase in the funding for military is important for increasing the military capability of India.

Art. 51A (h) says, it shall be the fundamental duty of every citizen of India to develop the scientific temper, humanism and the spirit of inquiry and reform. It is noted by APJ Abdul Kalam in his national security lecture that, "a nation is made by its people and people in turn become important citizens of that great nation. By importing non-strategic systems for defense (strategic system will not be available); a nation will not be able to defend both its economic freedom and security as this will only perpetuate the dependence on other nations. A country's strength to protect its security and evolve an independent foreign policy is dependent on the degree to which the nation is able to underpin this with self-reliance in defense and defense systems. India's core competence in certain technological areas and 
scientific technological man-power has to be harnessed. Through our sustained efforts for growth of core competence and self-reliance in critical technologies, we can transform our nation. We have to recognize that technology is the tool that brings faster economic growth and needed inputs for national security (Kalam \& Rajan, 1998). Self-reliance of a nation by APJ Abdul Kalam, indicated that man, machine and money is required to build 'Atmanirbhar' Bharat. Here the machine indicated defense technology; money indicated the funding and man indicates scientific tempered engineers who are having innovative ideas to make India 'Atmanirbhar' Bharat. It is very interestingly pointed out by Dr. Vijay Phandripande, former Vice Chancellor; in his article regarding noble prize noted that "the noble prize has been declared recently but as usual there is no Indian who has a complete academic qualification from Indian universities to get a noble prize, however it is a pity that there is no sensitivity in Indian people about this issue (https://maharashtratimes.com/editorial/ravivar-mata/dr-vijay-pandharipande-article-on-nobel -prize-and-india/articleshow/78591853.cms). This indicated the backwardness of education after completion of 70 years of Independence of India. As per Dr. Ambedkar education, health facility, insurance should be provided to citizens by government. At present education is privatized. In China education is provided by China government.

In above discussion the reality of India shows inequality in economic parameter and social parameter. This inequality in socio-economy is the root causes of weak democracy i.e., not a strong India, i.e., not having 'Atmanirbhar' Bharat. In 2020, it is rightly pointed out by Dr. B.R. Ambedkar in the parliament that, "on $26^{\text {th }}$ January 1950 we are going to enter in the life of contradiction. In politics we will have equality and in social and economic life we will have inequality. In politics we will be recognizing principle of 'one vote, one value'. In our social and economic life by the reason of our social and economic structure continue to deny the principle of 'one vote, one value'. How long we shall live to deny equality in our social and economic life? If we continue to deny it for long, we will do so by putting democracy in peril.' Before the policy of Globalization, Liberalization and Privatization, public sectors which are democratic institutions, used to nurture a democratic culture in the state by giving employment to the weaker section and backward community for uplifting their socio-economic life. After GLP policy, public sectors have become weak and are not able to continue the upliftment and welfare of the weaker section of Indian society. Constitutional mandate directs the State to strive for bringing equality, but due to lack of political will in executing that mandates India will not be able to achieve its goal of 'Atmanirbhar' Bharat.

It is rightly pointed out by Sri. T.N. Session, former Chief of Election Commission in his book 'Heartful Burden' that in India democracy is in an advance stage of decay. He added in his book that, election reform is very much needed in India. The experts say that if we are taking money from rich for election we have to prepare legislative law as per their will and wish. This environment will collapse the democratic structure slowly. At present money mafia and media have significant role in election. Supreme Court in the case of 'T.M.A. Foundation vs. Karnataka Govt' declared the result on dated $31^{\text {st }}$ Oct 2002, that the right to education of a citizen is not a fundamental right, whereas the right of private educational institutions imparting education is a fundamental right under the Art (19)(1)(g)." This 
judgment indirectly supports the commercialization of education. On this basis it can be said that it is big hurdle for poor population to get education. Without education poor population cannot become logical and skilled manpower.

As it has been pointed out by Professor Himanshu of Jawaharlal Nehru University that, "What is particularly worrying in India's case is that economic inequality is being added to society that is already fractured along the lines of caste, religion, region and gender" (OXFAM International, 2020). When we see the background of inequality in India, it is seen that traditionally the caste system is the root cause/disease in Indian society, illiteracy of India, poverty of India due to educational backwardness. The freedom fighters of India made a vision while framing the constitution for freedom, equality, fraternity and justice without any discrimination and opportunity to work in India. Further the parliamentarians made amendments and policies to make modern India. In Indira Gandhi government, family planning for population control, nationalization of bank for employment, ceiling act for land reforms, strengthening of public sector; are political targets which made justice for weaker section. In this period is evidence that there was a more participation of government. At present weakening the public sector and referring the new land law indicates less participation of government indicates reduced democratic culture and increased corporate culture it is rightly pointed by Dr. R.K. Shirsager that Dr. Ambedkar pressurized that "to put an obligation on the state to plan the economic life of the people onlines which would lead the highest point of productivity without closing every avenue to private enterprises and also provide for the equitable distribution of wealth" (Shirsagar, 2009). Referring the China dispute, it is to be remembered that the story of Buddha and Ajatshatru related to Wajji. In that story Buddha informed Ajatshatru that one can defeat Wajji after weakening of its democracy. Until the democracy is weakened in Wajji one cannot defeat it. China is afraid of Indian democracy. In practical Indian democracy is weakened due to minimized participation of government. In 1962, China defeated India due to carelessness of Dr. B.R. Ambedkar suggestions by Nehru government; in 2020, India has reduced funding of military expenditure and India has weak democracy present government should be careful of Dr. B.R. Ambedkar's thought which is in preamble of constitution. Dr. Ambedkar said I prefer soviet system; the collectivization of agriculture is the only way to our ills. the soviet system of agriculture is according to me the best." China's economy is based on collective farming. On this platform it is New Delhi to decide seriously the future danger of Indo-China dispute and execution of Indian constitutional mandate for 'Atmanirbhar' Bharat.

\section{Objective}

1) To analyze Indo-China issues for betterment of both the countries

2) To make India Atmanirbhar Bharat(self-reliant) as per Indian constitution

3) To suggest new model as a solution for Indo-China dispute in view of Dr. B.R. Ambedkar

\section{Research Methodology}

Research is a scientific endeavor based on systematic methods. the meaning of research has been explained in oxford dictionary as "a careful investigation or inquiry specially through 
search for new facts in any branch of knowledge" (Advanced learners dictionary of current English, 1952). In this article it is to be studied role of Dr. B.R. Ambedkar thought on Atmanirbhar Bharat with reference to Indo-China dispute. It is needed to be studied in social, economic, political and legal angle by adopting scientific research method, tools and technique

According to Clifford Woddy, "research comprises defining and redefining problems, formulating hypothesis or suggested solution, collecting organizing and evaluating data, making deduction and reducing conclusions and last carefully testing the conclusion to determine whether they fit for formatting hypothesis. We have to undergo through these processes" (Kothari, 2002). Limitation this research article is that due to Covid-19 pandemic field survey at the Indo-China border is not possible due to lockdown. Print Media survey of related issue in current newspapers and magazines are tested for this study to get current statistical data. It has been rightly noted that "the purpose of survey investigation, may also be provided scientifically gathered information to work as a basis for the researcher for their conclusion" (Kothari, 2002). Doctrinal method of research study is being made through literature survey through relevant reference books of present research article study. Samples and respondent are from north east region (Leh, Arunachal Pradesh, Sikkim) at Indo-China border, it is for pilot study. They communicated telephonically due to covid-19 pandemic lockdown in India.

\section{Findings}

1) Foreign policy is based on mutual interests of the countries. In this research project Indian national interest is the primary base. Indian constitution is the national interest. So foreign policies must be based on national interests provisioned as per articles of Indian constitution and not as per the interests of some big corporate houses collectively with some politicians of India. It is noted in Hindu new paper that "The -7.3 contraction of India GDP in FY21 was the biggest in at least 60 years as per provincial national income estimates released by national statistical office" (The Hindu, 2020). Former Prime Minister Jawaharlal Nehru said that government public sectors are new temples of modern India under his mixed economic policy. In Manmohan Singh government accepted. Open Economic policy which promoted globalization, liberalization, and privatization. It impacted negatively on public sector undertakings. It impacted on reservation policy negatively as scheduled caste/scheduled tribe backward lower caste community and women class are being minimized job opportunities and educational opportunities. This information received from telephonic communication with public sector employees/officers/advocates/engineers on work especially at north east region of India total 50 samples are from Leh, Sikkim, Arunachal Pradesh which are getting experience due to Indo-China dispute.

History of $19^{\text {th }}$ century repeated in India that Christian missionary started giving education to lower class Mahar, Manggirls without discrimination and Britisher's allowed Sudhra, Atisudhra (untouchables) in military job. Some upper-class community objected so Britisher's stopped military jobs for untouchables. Again in 1919 south-bureau commission, Simon commission 1927, in round table conference in 1930-32 Dr. B.R. Ambedkar 
advocated for military services and Britisher's agreed. In the result, Maharbattalion did participation in world $2^{\text {nd }}$ from British India.

Major finding with above historical relevance mixed economy will make Atmanirbhar Bharat as per advocacy of Dr. B.R. Ambedkar for inclusive democracy for strong socio-economy in India. Referring United Nations development program. Ranking of China shows 85 and India shows 129, Gross income of India shows 6,829, Gross income of China shows 16,127. This hence indicates that China's economy is better than Indian economy.

2) Caste System in India cultivates discrimination in the society. It effects negatively in unity, Upper caste population is on key posts and they are decision maker in judiciary, legislative, media, executive four organs of democracy. Lower caste people are still in low cadre posts they are weak decision maker due to their less participation in four organs of democracy. Even now also upper caste population of India has a majority in governance of India. They don't govern as per welfare state concept

3) Gender discrimination is traditional effect which is negative it impacts on unity in Indian society. Men have control over key posts they are decision maker due to their maximum participation. Women participation in judiciary, legislative, executive and media is miniscule as compared to male participation, whereas their physical population is $50 \%$ in the society equal to men population in the society. As per Pudharia regional newspaper Bill and Milinda gates foundation report 6.4 crore women lost their job in the world in India the report declared by action and association by surveying 20 states in India $79.20 \%$ jobs are lost by women in unorganized sector (Daily local newspaper Pudhari, 2021). Delhi should empower women under present governments slogan "betibacchav and betipadhav" i.e., "save daughter and educate daughter" remedial action is needed. Dr. B.R. Amdekar said that "I measure the progress of a community by the degree of the progress which women have achieved."

4) Right to work: It is pointed out by R. Nagraj who is visiting professor, Centre For Development Studies, Trivandrum in his editorial article in 'The Hindu' that the surge in total FDI inflow during the pandemic year is entirely explained by booming short term FIIs (Foreign Institutional Investors) in the capital market - and not adding to fixed investment and employment creation" (Nagraj, 2021). It indicates no employment creation in present 2019-2020 year by government. Right to work should be in fundamental right due to,

a. COVID-19 pandemic,

b. Minimizing rich poor gap, it is in directive principle as article 41 of Indian constitution

c. Improving productivity through young India. Present govt. announced make India concept but how to execute it is partly pending from Delhi. Poverty, unemployment, illiteracy all are interlinked which Indian government must think as a grave problem in annual budget. it is pointed by Dr. B.R. Ambedkar that "one of the principal duties of government must be to tackle the problem of poverty. The government must see that they do adopt ways and means whereby the national income of this province rises to some substantial level, whereby the majority of the people can live in amenities which rightly belong to all modern civilized men" and he concluded that this is the budget most disappointing budget, a budget which is 
designed to relieve the rich and to starve millions" (Dr. Babasaheb Ambedkar, 2005). Presently Parliamentarians should tackle poverty problem for Atmanirbhar Bharat

5) Education percolation theory for inclusive growth due to GLP policy and covid-19. Delhi should make education, medical facility provision digitally/online through government. Private education is costly. Poor and unemployed person can't afford it. Telecommunication department through BSNL to all village Gram-panchayat due to laying of optical fiber cable including at Indo-China border. E-education, e-health, e-manufacturing, etc. will help to make India Atmanirbhar Bharat.

\section{New Model}

1) Democracy in India is the largest democracy in the world. For more effective democratic governance electoral reform is needed under consideration of submission of Dr. B.R. Ambedkar in round table conference in London on 1930-32 for justified participation of all sections of Indian society for improved human development index in inclusive democracy with mixed economy, which is needful for Atmanirbhar Bharat.

2) Gender discrimination should be controlled by passing of $33 \%$ reservation of women bill in parliament in the view of Hindu code bill which introduced on $5^{\text {th }}$ Feb 1951 in the parliament by Dr. B.R. Ambedkarfor women justice who are $50 \%$ population in India, which is needful for Atmanirbhar Bharat.

3) Free education and medical facility should be to all by government for strong human resource. Secondly Employment provision in mass production companies and basic services industries under public sectors for strong economy as per views remarked in parliamentary debate by Dr. B.R. Ambedkar while discussing different economic articles in constitutional framing in 1947-50 period. Which is needful for Atmanirbhar Bharat?

4) Educated, healthy, and united Indians are effective human resource under government acting in the frame of Indian constitution (legal thought of Dr. B.R. Ambedkar) for Atmanirbhar Bharat, which is the effective solution for Indo-China dispute. QUAD (quadrilateral security dialogue) which is between India, USA, Japan, Australia for informal strategic dialogue between four democracies should considered as a standby arrangement.

\section{Conclusion}

Under Indo-China dispute situation it is needed that India should be Atmanirbhar Bharat means self-reliant. India can be self-reliant with strong socio-economy as per the social, political, economic, legal thoughts of Dr. B.R. Ambedkar the chairman of drafting committee of Indian constitution. Caste, gender, race discrimination is the disease in Indian society that is why Indian society is divided in different communities. Upper caste community is a big corporate and politicians. In BritishIndia period lower caste and women community got permission for Education and employment. So their representation participation matters in Indian democracy for united India. Indian constitution is effective socio-economic tool. But there is lacking in execution. So socially and economically India is now developing only. Privatization policy stopped public sectors so stopped employment of weaker section. 


\section{Al Macrothink}

International Journal of Social Science Research

ISSN 2327-5510

2021, Vol. 9, No. 2

Education and medical facilities are under private corporate. Till Indira Gandhi government only education institutions and medical facilities hospitals were established. So due to liberalization policy welfare state concept in Indian democracy is minimized. It resulted that no Noble prize for India in $21^{\text {st }}$ century and no university ranking in top world class universities. Wealth of nation should not be concentrated towards few capitalists. Freedom fighters of Indian independence struggle had a dream of providing freedom, equality, fraternity, justice for each citizens Delhi should be serious to change the priorities as per the freedom fighters dream which is in preamble of constitution if India want to settle the Indo-China dispute without war.

Dr. B.R. Ambedkar the chief architect Indian constitution thoughts support inclusive democratic principles for national security, public welfare, international peace and brotherhood. It is rightly pointed by Dr. B.R. Ambedkar that "an ideal society should be mobile, should be full of channels for conveying a change taking place in one part to other parts. in ideal society there should be many interests consciously communicated and sheared. There should be varied and free points of contact with other modes of association in other words there should be social endosmosis. This is fraternity which is only another name of democracy. Democracy is not merely a form of government. It is a form of associated living, of conjoint communicated experience. It is essentially an attitude of respect and reverence towards fellowmen" (vol. 1, p. 1).

To sum up, open economic policy is responsible in increasing rich poor gap in India. Mixed economy minimized caste and gender discrimination by inclusive socio-economic growth in India. Atmanirbhar Bharat as per the thoughts of Dr. B.R. Ambedkar will tackle the solution of Indo-China dispute in constructive way.

\section{References}

Abdul, K., \& Rajan, Y. S. (2020). India 2020: A Vision for New Millennium (1st ed. 1998, Ch. 1, p.5.). Penguin Books.

Aglave. (n.d.). Speech of Dr. Aglave. Retrieved from https://youtu.be/AIKkxOv16w

Alam, S. (2020). Outlook (p. 12). 12th October 2020.

Babasaheb, A. (2005). Writings and Speeches (Vol. 2, pp. 19-20).

Basu. (n.d.). Commentary on Indian Constitution.

Bidanda, C. (2020). OPINION: India's China policy merits re-thinking. The Week, 26th July 2020. Retrieved November 3, 2020, from https://www.theweek.in/news/india/2020/07/26/opinion-india-china-policy-merits-re-thinking .html

Kothari, C. R. (2002). Research Methodology (p. 1, 12). Delhi, WishwaPrakashan.

Nagraj, R. (2021). The Hindu. Mumbai, 2nd June 2021.

OXFAM International. (2020). India: Extreme inequality in numbers. Retrieved November 3, 


\section{Macrothink \\ International Journal of Social Science Research \\ ISSN 2327-5510 2021, Vol. 9, No. 2}

2020, from https://www.oxfam.org/en/india-extreme-inequality

Oxford. (1952). Advanced learners dictionary of current English (p. 1069).

Parliamentary Debates Rajya Sabha. (1954). A’s speech on India's foreign policy (vol. 7, pp. 469-483).

$\begin{array}{llll}\text { Retrieved } & \text { November } & 3, & \text { 2020, }\end{array}$ https://maharashtratimes.com/editorial/ravivar-mata/dr-vijay-pandharipande-article-on-nobelprize-and-india/articleshow/78591853.cms

Sandeep, U. (2020). India Today (p. 44). 19th October 2020.

Shirsagar, R. K. (2009). Aurangabad Municipal Commissioner (p. 47). Aurangabad.

Shyam, S. (2020). India Today (p. 18). 25th January 2020.

Somvanshi, B. C., \& Arthsastradnya. (2012). Dr. B.R. Ambedkar, Anand Prakashan Aurangabad (p. 14).

The Hindu, 1st June 2020, p. 1.

Daily local newspaper Pudhari, 03/06/2021, p-4

\section{Copyrights}

Copyright for this article is retained by the author(s), with first publication rights granted to the journal.

This is an open-access article distributed under the terms and conditions of the Creative Commons Attribution license (http://creativecommons.org/licenses/by/4.0/). 